This is a pre-copyedited, author-produced version of an article accepted for publication by

Elsevier in Journal of Environmental Psychology on 2017 following peer review, available online: https://doi.org/10.1016/j.jenvp.2017.10.008.

Journal of Environmental Psychology 54 (2017) 127-138

\title{
Affect and the adoption of pro-environmental behaviour: A structural model
}

\author{
Filipe Coelho ${ }^{\text {a, }}{ }^{*}$, Maria C. Pereira ${ }^{a}$, Luís Cruz ${ }^{a}$, Paula Simões ${ }^{b}$, Eduardo Barata ${ }^{a}$ \\ a Faculty of Economics / CeBER, University of Coimbra, Av. Dias da Silva 165, 3004-512 Coimbra, Portugal \\ ${ }^{\mathrm{b}}$ CeBER, University of Coimbra and School of Technology and Management, Polytechnic Institute of Leiria, Campus 2, Morro do Lena - Alto do Vieiro, \\ Apartado 4163, 2411-901 Leiria, Portugal
}

\section{A R T I C L E I N F O}

\section{Article history:}

Received 7 October 2016

Received in revised form

30 September 2017

Accepted 22 October 2017

Available online 23 October 2017

\section{Keywords:}

Pro-environmental behaviour

Trait affect

Environmental concern

Perceived consumer effectiveness

\section{A B S T R A C T}

Pro-environmental behaviour (PEB) is an essential part of changing societies towards a more sustainable future. The literature on PEB has provided significant insights into how the anticipated emotions arising from specific ecological actions contribute to environmentally friendly conduct. Our research departs from these studies by focusing on general affect as a determinant of PEB. Moreover, we specify mechanisms for the transmission effects of trait (rather than state) affect into PEB. We use structural equation modelling to test the hypotheses, with a sample of 925 individuals. The results show that the influence of positive affect on (reported) PEB is partially mediated by environmental concern and perceived consumer effectiveness. As to negative affect, the findings suggest only a direct effect on PEB. We also found differences between males and females. These are novel results that help to illuminate the complex issue of what shapes PEB, thereby supporting relevant theoretical and practical implications.

o 2017 Elsevier Ltd. All rights reserved. 


\section{Introduction}

Understanding what shapes an individual's predisposition to adopt pro-environmental behaviour (PEB) is a complex issue that is still not fully apprehended. Previous studies have taken into account many different factors, such as normative concerns, problem awareness/knowledge, and environmental attitudes (e.g., Bamberg \& Möser, 2007; Steg \& Vlek, 2009). Affect can also play an important role in influencing ecological behaviours as it influences the extent to which individuals interact with their surrounding environment, and because it determines the resources, psychological or other, that are available to them (Lyubomirsky, King, \& Diener, 2005). There have been, however, few studies of environmental psychology research on affect (e.g., Carrus, Passafaro, \& Bonnes, 2008; Kals, Schumacher, \& Montada, 1999; Koenig-Lewis, Palmer, Dermody, \& Urbye, 2014).

Affect is understood to be a broad term concerning both moods and emotions (Robbins, Judge, Millett, \& Jones, 2010). Affect "refers to consciously accessible feelings" (Fredrickson, 2001, p. 2), i.e., it comprises the subjective experiences of individuals (Wyer, Clore, \& Isbell, 1999), covering a wide spectrum of feelings, such as sadness, enthusiasm and happiness. Emotions tend to be more intense, short-lived feelings, and are associated with some specific stimuli (Fredrickson, 2001), whereas moods concern subjective experiences that are less intense, have no specifiable causes, and are more long-lasting (Forgas \& George, 2001). Moreover, the literature distinguishes between trait affect and state affect. While state affect concerns an individual's feelings at a certain point in time, trait affect concerns individual differences regarding the extent to which individuals tend to experience specific affective states across time (Thoresen, Kaplan, Barsky, Warren, \& de Chermont, 2003; Watson, 2000).

Past research on the role of affect in explaining PEB has been mainly focused on state affect, neglecting trait affect. The trait approach is important because it is associated with a predisposition to think and behave in a systematic way, whereas the focus on state affect is 
related to PEB that results from situational determinants (cf. Schaubroeck, Ganster, \& Kemmerer, 2016). Actually, the adoption of PEB is likely to be demanding for individuals, requiring them to spend time, and greater cognitive effort in pondering the additional purchase attributes, as well as economical and psychological resources. Hence, by influencing resources and willingness to engage in various life activities, trait affect should influence an individual's long-term environmental attitudes and behaviours.

The influence of affect on behaviour has often been shown to be mediated by other factors, such as attitudes, norms and risk perceptions (Curry \& Youngblade, 2006; Han, 2014; Perugini \& Bagozzi, 2001; Vining \& Ebreo, 2002). It is plausible that also the effects of trait affect on PEB may be mediated by other factors, including environmental concern (EC) and perceived consumer effectiveness (PCE). Hence, the aim of this paper is to investigate both the direct and indirect influences of trait affect on PEB through EC and PCE, which are key to systematic behaviours towards the environment.

\section{Research background and hypotheses}

Axelrod and Lehman (1993, p. 153) define PEB as those "actions that contribute to the preservation and/or conservation of the environment". More recently, Stern (2000, p. 408) defined environmentally significant behaviour as "behaviour that has a positive impact on the availability of materials or energy and that positively alters the structure and dynamics of ecosystems or the biosphere". These concepts include actions aimed at avoiding damaging, or rehabilitating, the environment, which can be performed individually or collectively, and which impact directly or indirectly upon it. Following the pioneering work of Gardner and Stern (1996), and similarly to Stern (2000), Lee, Kim, Kim and Choi (2014) classify such actions into three broad categories of PEB: green purchases (the purchase of recycled goods or non-toxic substances), good citizenship (the minimisation of energy consumption, water conservation, along with the reduction of waste production and promotion of recycling), and environmental 
activism (environmental group membership). In line with Milfont and Duckitt $(2004,2010)$ and Zhao, Gao, Wu, Wang and Zhu (2014), this study approaches PEB as being comprised of both green purchases and good citizenship behaviour, as detailed in the methodology.

\subsection{Affect and pro-environmental behaviour}

Forgas and George (2001) argue that individuals' thinking and behaviours take place in an affective context, and that it is through cognition that the latter influences individuals' judgments and behaviours. Affect has most commonly been structured around a positive and negative valence (e.g., Thoresen et al., 2003). Positive affect (PA) concerns the extent to which individuals describe themselves as feeling joyful, energetic, alert, enthusiastic or fully concentrated. Negative affect (NA) comprises emotions such as fear, anxiety and sadness (Watson, Clark, \& Tellegen, 1988).

Early research suggested that individuals high in PA process negative information in a superficial way (Isen, 2008). More recently, a considerable amount of research has proved otherwise (e.g., Isen, 2008). These works have shown that PA enhances thoroughness in processing both positive as well as negative information (Aspinwall, 1998). In this context, individuals scoring higher on PA tend to "approach their environment with more favourable expectations, and display a stronger willingness and enthusiasm to seek out and actively engage in various life events" (Kuiper, McKee, Kazarian, \& Olinger, 2000, p. 480). Conversely, individuals with higher levels of NA tend to perceive the world surrounding them in a negative manner (Kuiper et al., 2000), and withdraw "into a self-protective stance in which the primary aim is to protect his or her existing resources and to avoid harm" (Lyubomirsky et al., 2005, p. 804). Importantly, it has been argued that positive and negative processes are functionally independent and not opposites along the same continuum (Russell \& Carroll, 1999).

Trait measures of NA and PA have been related to personality traits. Considering only the "Big Two" traits of personality, Watson, Wiese, Vaidya and Tellegen (1999, p. 829) concluded 
that trait measures of NA are correlated with Neuroticism, as they reflect stable individual differences in regard to the tendency to experience aversive emotional states, while trait PA measures are more related to Extraversion, as they evaluate characteristic differences in the experience of positive states. Personality traits, in turn, have been related to different aspects of environmentalism, namely environmental concern, engagement and behaviour. The "Big Five" model of personality (Agreeableness, Conscientiousness, Extraversion, Neuroticism and Openness to experience) (Goldberg, 1990) has been used in this context (Brick \& Lewis, 2014; Hirsh, 2010; Markowitz, Goldberg, Ashton, \& Lee, 2012; Milfont \& Sibley, 2012; Terrier, Kim, \& Fernandez, 2016). Other stable individual differences, such as locus of control and personal responsibility (see Bamberg \& Möser, 2007), have also been related to environmental issues, thereby supporting our trait approach to affect.

The role of affective aspects in explaining PEB has been considered in a number of studies. One stream of research considers individuals' emotional connectedness to nature, based on the biophilia hypothesis, according to which "humans possess a biologically based attraction to nature" (Kals et al., 1999, p. 183). Such an emotional affinity towards nature is a strong predictor of ecological behaviour (Mayer \& Frantz, 2004). Emotions have also been studied in the environmental education domain. Pooley and O'Connor (2000) have demonstrated that what people feel and believe about the environment influences their attitude towards it, and have appealed to the need to target affect in educating people about the environment. Vaske and Kobrin (2001) suggest that promoting attachment to a local natural resource influences environmentally responsible behaviours in other facets of life.

Another stream of the literature has considered that PEB is the outcome of individuals' anticipated negative and/or positive emotions resulting from the adoption of such behaviours (Carrus et al., 2008; Han, 2014; Han, Hwang, \& Lee, 2017; Koenig-Lewis et al., 2014; Wester et al., 2015). Hence, in these studies, PEB is not the result of a general affective state. An exception to this is 
Bissing-Olson, Iyer, Fielding and Zacher (2013), who analysed the relationship between state (daily) affect and environmental behaviour, although their work was focused on the study of employees' PEB at work. Moreover, they investigated how the role of daily affect was moderated by EC. The research established that a pro-environmental attitude and daily unactivated PA positively predict an employee's PEB while they are performing their daily tasks.

Finally, several studies have looked at specific emotions like guilt in investigating PEB. However, Watson (2000, p. 32) argues that "pure, unmixed affective states are relatively rare in everyday life" and that when individuals report one type of emotion, such as depression, they also tend to report hostility and anxiety. He concludes that more general models of affect overcome some conceptual and data-analytic problems, namely redundancy and high correlations. Although emotions like guilt and sadness provide more specificity (Wester et al., 2015), in this study we follow a broader approach to affect, namely PA and NA, which has frequently been used in other contexts (see the meta reviews by Thoresen et al. (2003) and Giluk (2009)). Hence, our study departs from past studies focusing on affect and PEB by considering general affective experiences and, in particular, trait affect, rather than state affect, or anticipated affective states arising from performing certain environmental behaviours. Moreover, we also depart from Bissing-Olson et al. (2013) by predicting that trait affect leads to EC. Trait affect has been related to substance use and risky sexual behaviours (Mezzich et al., 1997), counterproductive workplace behaviour (Samnani, Salamon, \& Singh, 2014), and prosocial or altruistic behaviour in an organisational context (Forgas \& George, 2001). This evidence further paves the way for expecting trait affect to be related to PEB. Accordingly, we develop a model in which PA and NA are directly and indirectly related to the adoption of environmentally-friendly behaviours. 
Affect influences both what we think and how we think (Forgas \& George, 2001). Therefore, we predict that affect will influence EC. EC taps “"primitive beliefs' about the nature of the earth and humanity's relationship with it" (Dunlap, Liere, Mertig, \& Jones, 2000, p. 427). Such beliefs should impact upon more particular beliefs and attitudes about the environment (Mayer \& Frantz, 2004). Similarly, Bamberg and Möser (2007) note that EC refers to an awareness of, and being knowledgeable about, environmental problems.

Moreover, following Fredrickson's (1998, p. 300) suggestion that positive emotions "broaden an individual's momentary thought-action repertoire, which in turn has the effect of building that individual's physical, intellectual and social resources", we predict that affect will relate to both PCE and PEB. PCE concerns an individual's belief that he or she can make a difference in contributing to the preservation of the environment (Ellen, Wiener, \& CobbWalgren, 1991). PCE is closely aligned with the concept of self-efficacy, which has been defined as the "belief in one's capabilities to mobilize the motivation, cognitive resources, and courses of action needed to meet given situational demands" (Wood \& Bandura, 1989, p. 408). Such perceptions are formed from information drawn from the individual, as well as from his or her experiences, and from others in his/her environment (Gist \& Mitchell, 1992). Hence, our model considers that EC and PCE partially mediate the influence of affect on PEB. In summary, a great variety of analytical frameworks and factors have been used to explain the adoption of PEB (Hines, Hungerford, \& Tomera, 1987), and these make it impossible to develop a single model capturing all of these influences (Kollmuss \& Agyeman, 2002). Therefore, this paper proposes a model focused on the trait affect perspective, which is depicted in Figure 1. 
Figure 1: A model of the influence of trait affect on pro-environmental behaviour

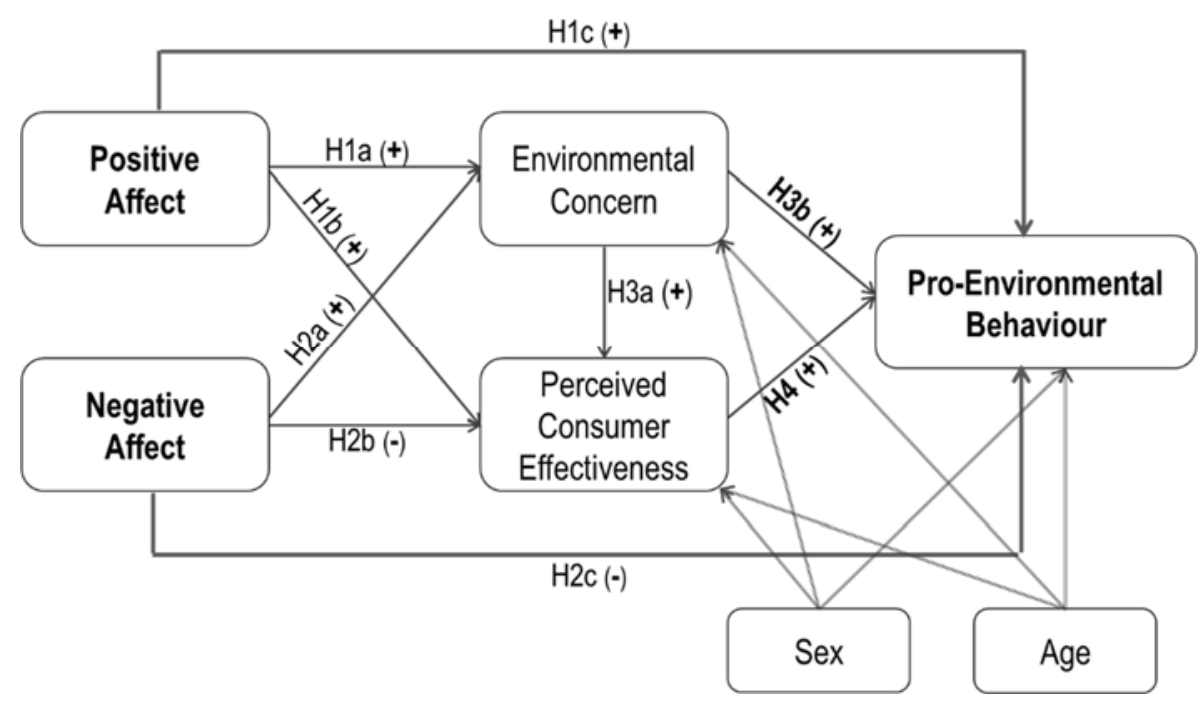

\subsection{Research Hypotheses}

\section{Positive affect and environmental concern}

Research shows that PA enhances thoroughness in processing both positive as well as negative information (Aspinwall, 1998). In particular, individuals in a positive mood, upon receiving important negative information (i.e., presenting a serious threat), may pay more attention to it and engage in greater cognitive processing efforts (Aspinwall, 1998; Isen, Shalker, Clark, \& Karp, 1978). In addition, research on the influence of PA on thought processes demonstrates "more flexibility in information-processing strategies, and generally enhanced thinking and problem solving whenever a person has reason to engage a problem fully" (Isen, 2008, p. 549). Hence, PA facilitates information-processing strategies by promoting access to positive material that has been stored in the memory, while simultaneously not obstructing access to relevant negative material (Isen, 2008, p. 548). Moreover, the Broaden-and-Build Model of Positive Emotions (Fredrickson, 1998) notes that PA contributes to an expanded attentional scope. The level of environmental degradation is mounting, and this makes it a pressing issue for humanity (Harth, Leach, \& Kessler, 2013; Wester et al., 2015). Accordingly, a high PA should drive individuals to attend more rigorously to relevant 
information, including that regarding the environment, yielding a more complete view of environmental problems. Therefore, individuals in a positive mood are more likely to develop a concern for the environment. Hence, we offer the following hypothesis:

H1a: Positive affect is positively related to environmental concern.

\section{Positive affect and perceived consumer effectiveness}

Fredrickson (1998) proposes that positive emotions expand an individual's stock of thought-actions, thereby building their permanent resources, which can be accumulated over time and used later. Likewise, Aspinwall (1998) argues that PA provides psychological resources that facilitate engagement in proactive or preventive behaviours, like counteracting health threats. These behaviours require individuals to incur short-term costs in the pursuit of long-term benefits, and this may demand time and money, as well as psychological and other resources from individuals. Aspinwall (1998) concludes that PA influences “people's appraisals of the strength or adequacy of their resources to withstand negative events and information", and Lyubomirsky et al. (2005) argue that it is associated with more positive perceptions of the self. Not surprisingly, individuals high in PA tend to set higher personal goals (Hom \& Arbuckle, 1988), and report higher self-efficacy (Jundt \& Hinsz, 2001). An individual's perception of their capabilities is a key motivational tool, which determines their expenditure of effort as well as the cognitive resources and behaviours needed to effectively perform well on a task (Wood \& Bandura, 1989). Hence, self-efficacy and therefore PCE constitute an important psychological resource. In this context, individuals high in PA, when subjected to negative information, namely about the environment and their impact upon it, will work to improve their performance on such matters (Aspinwall, 1998). Moreover, PA should facilitate the build-up of resources required by the adoption of PEB, and induce a more positive assessment of one's ability to cater for a better environment. Hence, the following hypothesis is offered: 
H1b: Positive affect is positively related to perceived consumer effectiveness.

\section{Positive affect and pro-environmental behaviour}

Positive emotions broaden the scope of action, motivating people "to engage with their environments and partake in activities, many of which are adaptive for the individual, its species, or both", helping to prepare for future challenges (Fredrickson, 2001, p. 2). Furthermore, individuals with high PA seem to be more helpful and contributive to their communities (Lyubomirsky et al., 2005). For example, it is argued that PA fosters the anticipation of positive outcomes such as gratitude rather than the costs of helpful behaviours (Cunningham, 1988). Therefore, the greater involvement of individuals high in PA with their surrounding environment should enhance their participation in activities that are perceived to reduce or eliminate the negative environmental impacts of mankind in the world. Bissing-Olson et al. (2013) draw on the literature showing that PA leads to pro-social or altruistic behaviour directed to public goods, and argue that PEB can be seen as helping behaviours that are specifically targeted at the environment. Furthermore, the adoption of PEB is costly, demanding extra physical and/or cognitive efforts from individuals. PA appears to facilitate such efforts, namely by positively signalling the adequacy of one's resources, and by influencing the weight of the immediate costs against future gains (Trope \& Pomerantz, 1998). Finally, the adaptive concerns of individuals high in PA should include the environment, which is demanding increasing attention and action (Harth et al., 2013; Wester et al., 2015), and this should result in greater PEB. Given the above arguments, the following hypothesis is proposed:

H1c: Positive affect is positively related to pro-environmental behaviour.

\section{Negative affect and environmental concern}

Affect determines the type of information to which individuals attend (Necowitz \& Roznowski, 1994). NA reduces individuals' cognitive efforts to move attention away from negative information about the world around them (Judge, Erez, \& Thoresen, 2000), and 
heightens the susceptibility of individuals to adopting dysfunctional psychological processes, including the encoding and recalling of negative information (Weiss \& Cropanzano, 1996). Moreover, as NA increases, so does the responsiveness to the induction of negative mood (Larsen \& Ketelaar, 1991), as well as the threshold for responsiveness to positive inducements (Brief, Butcher, \& Roberson, 1995). Accordingly, a tendency to portray the world through a negative lens is likely to contaminate an individual's view about the environment itself. More specifically, it is likely that high NA will lead individuals to focus their attention on negative information about the environment, thus raising concerns about it. Accordingly, we propose the following hypothesis:

H2a: Negative affect is positively related to environmental concern.

\section{Negative affect and perceived consumer effectiveness}

The inability to steer the attentional focus of their cognitive efforts away from negative issues makes individuals high in NA feel more exposed to daily hassles (Bolger \& Schilling, 1991), and experience more strain (Judge et al., 2000). As a result, these individuals are less likely to have the motivation and ability to build-up their personal resources. Moreover, NA is associated with the utilisation of ineffective coping strategies (Watson \& Hubbard, 1996). Thoresen et al. (2003) and Aspinwall (1998) note that theories of mood-congruent processing predict that, in general, negative moods lead to less favourable judgments, namely about oneself. As a consequence, unhappy and sad people have lower self-esteem, and tend to have a worse perception of their self-efficacy (Dua, 1993; Kavanagh \& Bower, 1985). Accordingly, NA is likely to be detrimental to PCE, as feelings of mastery depend on the accumulation of positive past experiences (Gist \& Mitchell, 1992), which such individuals are less likely to have. It also follows that individuals high in NA should have worse perceptions of their ability to positively contribute to the environment, as well as less motivation and a lower ability to 
develop their personal resources in terms of how they can ameliorate the impact they have on the environment. Hence, we hypothesise that:

$\mathrm{H} 2 \mathrm{~b}$ : Negative affect is negatively related to perceived consumer effectiveness.

\section{Negative affect and pro-environmental behaviour}

The adoption of proactive or preventive behaviours requires resources (Aspinwall, 1998; Fredrickson, 1998). In contrast to individuals high in PA, who most likely have accumulated them during previous experiences, individuals high in NA are not in possession of the required physical, social and psychological resources. Moreover, research indicates that positive moods generally act as a motivational force in regard to the adoption of helping behaviours, whilst negative moods lead to helping only under certain conditions. Lyubomirsky et al. (2005) note that this is the case when the benefits of helping are high compared to the respective costs, such as when individuals think that they have harmed others, or think that by helping others they will improve their own mood. Hence, such a diminished propensity to help is likely to lead to a narrower predisposition to engage in PEB. In addition, pursuing PEB entails short-term costs. In this context, an individual's decisions rest on how they weigh these costs against the longterm and often blurred benefits resulting from such behaviour, with the balance adversely affecting the adoption of PEB for those high in NA. Moreover, the lower psychological and physical resources built over time by individuals high in NA should reduce their propensity for adopting PEB (cf. Fredrickson, 2001), which can be resource demanding. In summary, individuals high in NA are less likely to make an effort to achieve relevant goals, such as behaving in an environmentally friendly way. Accordingly, we offer the following hypothesis: $\mathrm{H} 2 \mathrm{c}$ : Negative affect is negatively related to pro-environmental behaviour.

\section{Environmental concern and perceived consumer effectiveness}

Following the norm activation theory (Schwartz, 1977), EC should activate an individual's feeling of being obliged to perform PEB. We argue that such feelings of obligation motivate 
individuals to explore how they can contribute to a better environment. Following Gist and Mitchell (1992), an individual's self-efficacy perceptions depend on a number of factors, including his or her motivation to make an effort to learn, which, in turn, is influenced, e.g., by his/her priorities, interests and goals. Accordingly, the learning endeavour motivated by EC should result in an improvement in PCE, as it leads individuals to develop "cognitive, behavioural, and self-regulatory tools" (Wang \& Netemyer, 2002, p. 220), including knowledge about the environment and its protection. Such knowledge and tools should improve individuals' understanding of the functioning of the environment, enable them to better predict the outcomes of their behaviours, and identify effective courses of action to mitigate the adverse effects of their actions in the environment, as well as the physical and psychological resources available to pursue PEB. Hence, we propose the following hypothesis:

H3a: Environmental concern is positively related to perceived consumer effectiveness.

\section{Environmental concern and pro-environmental behaviour}

Numerous studies have recognised and supported the positive effect that EC is likely to have on PEB (Bamberg \& Möser, 2007; Hines et al., 1987; Rhead, Elliot, \& Upham, 2015). An explanation of this relationship is that being aware and knowledgeable about environmental problems is a precondition for the development of moral norms (Bamberg \& Möser, 2007), which lead individuals to adopt pro-social behaviours (Schwartz, 1977), in our case behaviours that minimise the impact of humankind on the natural environment. However, the strength of this link varies across studies (Fransson \& Gärling, 1999). Such studies provide evidence regarding the influence of EC on the adoption of broad environmental behaviours (Lee et al., 2014), as well as specific ones, such as energy saving (Hori, Kondo, Nogata, \& Ben, 2013; Sardianou, 2008), green purchases (Chan, 2001; Lin \& Huang, 2012), recycling (López-Mosquera, Lera-López, \& Sánchez, 2015; Park \& Ha, 2012) and the choice of ecological transportation (López-Mosquera et al., 2015; Passafaro et al., 2014). Accordingly, we replicate previous studies by hypothesising that: 
H3b: Environmental concern is positively related to pro-environmental behaviour.

\section{Perceived consumer effectiveness and pro-environmental behaviour}

Empirical research on the effect of PCE on PEB dates back to the 1970s (Kinnear, Taylor, \& Ahmed, 1974; Webster, 1975). Underlying this relationship is the idea that individuals' behaviours are influenced by the extent to which they perceive that certain events are affected by their actions (Thompson, 1981). Accordingly, individuals who believe that they can make a positive impact on the environment are more likely to adopt the corresponding behaviours (Ellen et al., 1991). Consistent empirical evidence has supported this relationship (e.g., Akehurst, Afonso, \& Gonçalves, 2012; Ellen

et al., 1991; Lee et al., 2014; Vicente-Molina, Fernández-Sáinz, \& Izagirre-Olaizola, 2013). For example, Lee et al. (2014) concluded that PCE is positively related to three types of PEB, namely green purchases, good citizenship behaviour and environmental activism. Thus, we adopt the following hypothesis:

H4: Perceived consumer effectiveness is positively related to pro-environmental behaviour.

\section{Methodology}

\subsection{Data collection}

The data for this research was collected with the collaboration of a group of schools from a Portuguese municipality. Approximately 1,600 questionnaires were distributed through form teachers, who asked the students to deliver them to their parents and return them inside the anonymous closed envelope that accompanied the questionnaire, within a week. Instructions were given to these collaborators regarding the optional nature of participation in the study, as well as the anonymity of the questionnaire. The questionnaire pack included a cover letter motivating the parents to participate in the study and assuring them of the anonymity and confidentiality of their responses.

We obtained 925 usable questionnaires, giving a net response rate of $57.8 \%$. In our sample, 740 of the respondents are females $(80 \%)$ and 185 are males $(20 \%)$. The respondents' ages vary 
within the 20-74 bracket $(\mathrm{M}=40.36 ; \mathrm{SD}=6.9)$. In terms of marital status, most of the respondents $(83.3 \%)$ are married or living with a partner. As to education, $32.1 \%$ of the individuals have completed the 3 rd cycle of basic education (corresponding to 9 years of schooling), $24.8 \%$ have completed secondary education, and $19.1 \%$ have a university degree. Concerning the monthly household net income distribution, most of the respondents are in the 500-999€ bracket (34.5\%), followed by the $1000-1499 €(28 \%), 1500-2499 €(17.9 \%)$ and $0-500 €(14.2 \%)$ brackets.

\subsection{Measurement and measurement properties}

The questionnaire was pre-tested and relied on previously-validated scales. To measure the degree of positive or negative subjective experiences of individuals (PA and NA) we relied on the ten-item PANAS short form from Mackinnon et al. (1999), which has been used in a wide variety of research settings (e.g., Lu \& Schuldt, 2016; Wong, Newton, \& Newton, 2016). The extent to which individuals adopt behaviours that minimise humankind's impact on the natural environment (PEB) was based on Milfont and Duckitt (2004, 2010) and Zhao et al. (2014), with two items being dropped as they were not considered adequate in the Portuguese context. This is a conventional measure of PEB, which captures both (private-sphere) good citizenship behaviour and green purchase behaviour, while other authors (Lee et al., 2014; Stern, 2000) have proposed multidimensional scales that also contain public-sphere behaviour. EC is measured with four items used by Lee et al. (2014), which they took from the revised NEP scale (Dunlap et al., 2000) - shorter versions of the NEP scale are frequently used (e.g., Cordano, Welcomer, \& Scherer, 2003; Hartmann \& Apaolaza-Ibáñez, 2012). Finally, PCE is a four-item scale based on Obermiller (1995). It should be noted that we formed an index for reported PEB by averaging the 11 items, as the responses to the items do not necessarily have to correlate with one another (Steg \& Vlek, 2009). 
Prior to running the confirmatory factor analysis (CFA), we resorted to item-parcelling, a common practice in latent variable analysis that involves aggregating two or more items (Little, Cunningham, Shahar, \& Widaman, 2002). Little, Rhemtulla, Gibson and Schoemann (2013) note that the centroid of a construct measured by parcels tends to be closer to the construct's true centroid than the estimated factor centroid relying on single items. Item parcelling has other psychometric and empirical modelling advantages (e.g., Coffman \& MacCallum, 2005; Little et al., 2002, 2013). In terms of psychometric advantages, parcels offer higher reliability and suffer less from distributional violations. In terms of model estimation, parcels offer advantages such as being less likely to evidence dual-factor loadings, correlated residuals and reduced sources of sampling error. To build the parcels, we relied on random assignment (Little et al., 2002). Given the desirability of having at least three indicators per factor (Kline, 2011), we only applied item parcelling to PA and NA, each with five items. We note that these constructs are unidimensional, a prerequisite to item parcelling (Bandalos, 2002). Accordingly, each of these constructs was modelled with two parcels of two items each plus one unparcelled indicator. The results of the estimation of the CFA model indicated no need for model respecification. Moreover, the fit of the CFA model was quite reasonable: $\chi^{2}=198.20$, df $=81 \mathrm{p}<.01$, Incremental Fit Index $[\mathrm{IFI}]=.98$, Tucker-Lewis Index $[\mathrm{TLI}]=.97$, Comparative Fit Index $[\mathrm{CFI}]=.98$, Root Mean Square Error of Approximation $[\mathrm{RMSEA}]=.04$. In addition, the magnitude of the factor loadings was large, as was their statistical significance, with the lowest critical ratio being above 18 . This evidence supports convergent validity. The average variance extracted (AVE) for each construct was above the recommended level of .50 (Fornell \& Larcker, 1981). The composite reliabilities also exceeded the .70 threshold. Finally, we found that there is discriminant validity, as all of the AVE are larger than the corresponding squared correlations between any two pairs of constructs (Fornell \& Larcker, 1981). Overall, this is evidence that the measures we used meet the existing guidelines concerning reliability and 
validity. Table 1 presents the standardised loadings from the CFA after the item-parcelling process. Table 2 presents the correlation coefficients, as well as the Cronbach Alphas, AVE, and composite reliabilities.

Table 1. Confirmatory Factor Analysis results

\begin{tabular}{|c|c|c|}
\hline Constructs and items & $\begin{array}{c}\text { Stand. } \\
\text { Loadings }\end{array}$ & t-value \\
\hline \multicolumn{3}{|l|}{ Positive affect } \\
\hline Excited / Inspired (parcel) & .61 & 18.10 \\
\hline Determined & .72 & 21.64 \\
\hline Enthusiastic / Alert (parcel) & .85 & 25.33 \\
\hline \multicolumn{3}{|l|}{ Negative affect } \\
\hline Upset & .67 & 21.19 \\
\hline Scared / Distressed (parcel) & .79 & 25.35 \\
\hline Afraid / Nervous (parcel) & .88 & 28.93 \\
\hline \multicolumn{3}{|l|}{ Environmental concern } \\
\hline $\begin{array}{l}\text { If things continue on their present course, we will soon experience a major ecological } \\
\text { catastrophe }\end{array}$ & .67 & 21.63 \\
\hline Humans are severely abusing the environment & .76 & 25.68 \\
\hline The balance of nature is very delicate and easily upset & .84 & 29.45 \\
\hline $\begin{array}{l}\text { Despite having special abilities, humans are prone to serious risks if they upset the } \\
\text { laws of nature }\end{array}$ & .77 & 26.08 \\
\hline \multicolumn{3}{|l|}{ Perceived consumer effectiveness } \\
\hline There is a lot that any one individual can do about the environment & .75 & 25.24 \\
\hline $\begin{array}{l}\text { The conservation efforts of one person are useful even when other people refuse to } \\
\text { conserve }\end{array}$ & .65 & 20.67 \\
\hline Each citizen can contribute to solving the environmental problems & .86 & 30.20 \\
\hline My actions can help reduce pollution and deal with natural resource scarcity & .73 & 24.08 \\
\hline Pro-environmental behaviour (index measure) & 1.00 & 42.94 \\
\hline Reuse water & n.a. & \\
\hline Use energy saving light bulbs & n.a. & \\
\hline Try to buy energy efficient household appliances & n.a. & \\
\hline Conserve petrol by walking or cycling & n.a. & \\
\hline Recycle cardboard, paper and paper made products & n.a. & \\
\hline Recycle cans and aluminium/metal recipients & n.a. & \\
\hline Buy products made or packaged with recycled materials & n.a. & \\
\hline Reuse things/objects & n.a. & \\
\hline Encourage friends and family to recycle & n.a. & \\
\hline Pick up litter that is not mine & n.a. & \\
\hline Reuse paper or plastic bags & n.a. & \\
\hline
\end{tabular}

Table 2. Correlation matrix, standard deviation, reliability and variance extracted

\begin{tabular}{l|rrrrr|rrr}
\hline \multicolumn{1}{c}{ PA } & NA & EC & PCE & PEB & SD & CR & AVE \\
\hline PA & $\mathbf{. 7 6}$ & & & & & .56 & .78 & .54 \\
NA & -.18 & $\mathbf{. 8 2}$ & & & & .87 & .83 & .61 \\
EC & .12 & .03 & $\mathbf{. 8 4}$ & & & .58 & .85 & .58 \\
PCE & .23 & -.02 & .61 & $\mathbf{. 8 3}$ & & .54 & .84 & .56 \\
PEB & .17 & -.08 & .23 & .32 & n.a. & .61 & - & - \\
\hline
\end{tabular}

Notes: PA - Positive affect; NA - Negative affect; EC - Environmental concern; PCE - Perceived consumer effectiveness; PEB - Pro-environmental behaviour; Diagonal entries are Cronbach's alpha coefficients; SD - Standard deviation; CR - Composite reliability; AVE - Average variance extracted. 
The deviation to normality in our data is modest, and therefore does not endanger the findings and interpretations from the maximum likelihood estimations (Fan \& Wang, 1998; Lei \& Lomax, 2005).

To assess the magnitude of Common Method Variance (CMV), we employed a number of tests. Initially, we conducted the Harmon-one factor test. The first factor only retained $29.07 \%$ of the variance, far from accounting for the majority of the variance in the data. In addition, we also followed a procedure involving a comparison of simpler and more complex models (Chaudhuri \& Ligas, 2009). If simpler models, with fewer factors, fit similarly or even better than models with more factors, this is indicative that CMV is an issue. Accordingly, we ran different models with a smaller number of factors by combining the items from different measures into the same construct. However, a number of chi-square difference tests indicated that the fit of the original five factor model, the largest model, was always significantly better than any other smaller models, and this is also indicative that CMV should not affect the results in a substantive manner. Finally, the hypothesised five factor measurement model fits much better than a single factor model, and this also supports no severe CMV (Kafetsios \& Zampetakis, 2008).

\section{Results}

To test the research hypotheses, we used structural equation modelling, relying on the AMOS software version 22. The estimation of the hypothesised model yielded the following statistics: chi-square=226.92, $\mathrm{df}=101(\mathrm{p}<.001) ; \mathrm{IFI}=.97 ; \mathrm{CFI}=.97, \mathrm{TLI}=.97 ; \mathrm{RMSEA}=.04$. Given the imbalance in the sample in terms of sex, we conducted a multi-group analysis, the results of which are considered in the discussion. We subsequently describe the results (see Table 3) of the hypotheses testing. $\mathrm{H} 1$ predicted that PA is positively related to EC. This is supported by the results, since the coefficient is positive and significant $(b=.14 ; p<.01)$. The results also denote that PA is significant and positively related to $\mathrm{PCE}(\mathrm{b}=.16 ; \mathrm{p}<.01)$, which is 
in accordance with $\mathrm{H} 1 \mathrm{~b}$. Finally, H1c predicted that PA would relate positively to PEB. This is also supported as the coefficient is positive and significant $(b=.10 ; p<.01)$. With regard to the three hypotheses involving NA, only one receives support. H2a predicted that NA would be positively related to EC. This hypothesis is not supported, given that the coefficient is nonsignificant $(\mathrm{b}=.06 ; \mathrm{p}>.05)$. $\mathrm{H} 2 \mathrm{~b}$ predicted that NA would be negatively related to PCE, but this is also not supported, as the coefficient is non-significant $(b=-.00 ; p>.05)$. NA is negatively related to PEB $(b=-.06 ; p<.05)$, and this is in accordance with our projection $(\mathrm{H} 2 \mathrm{c})$.

Table 3. Results of the structural model

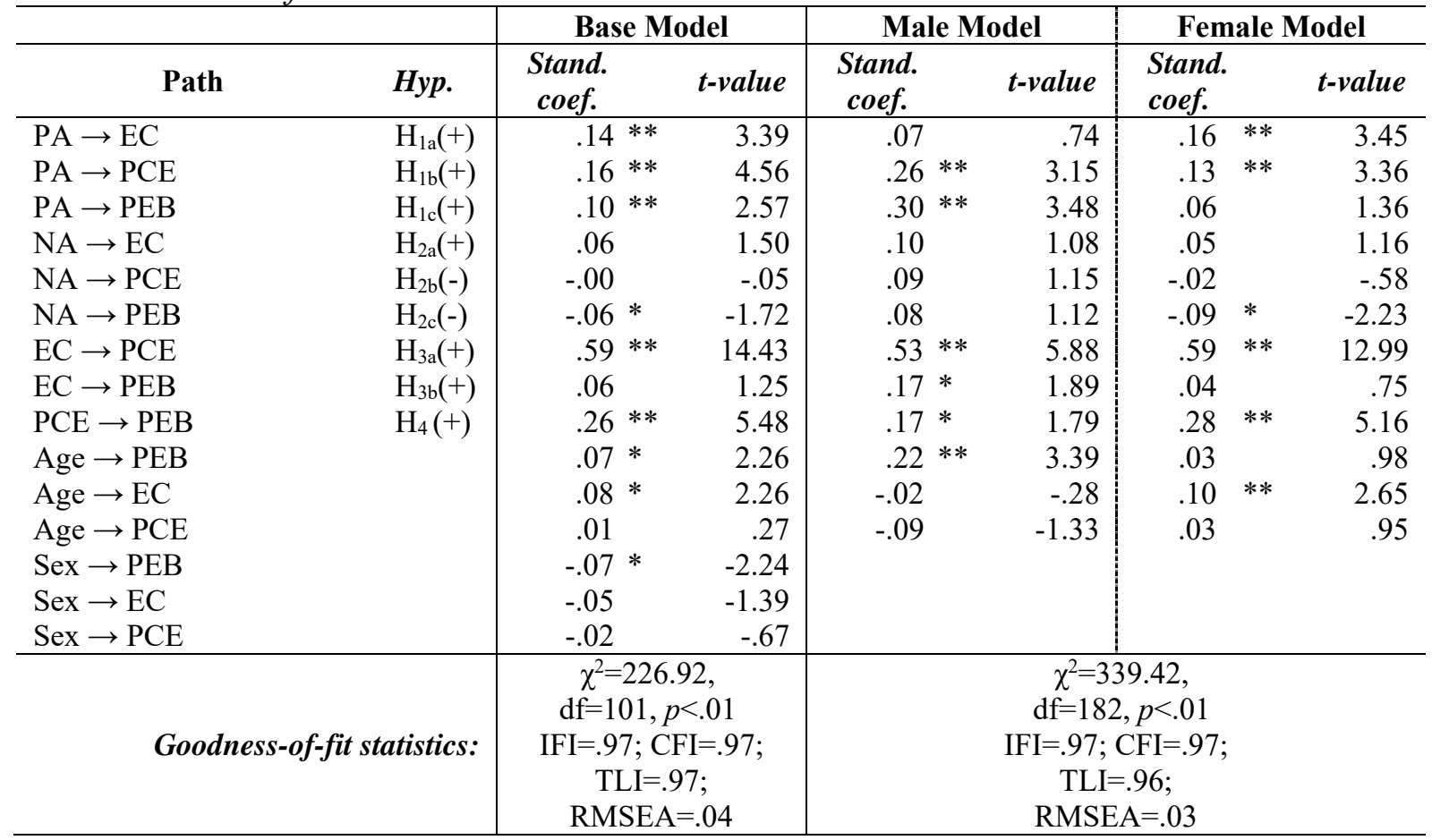

Notes: $* \mathrm{p}<.05 ; * * \mathrm{p}<.01$ (one tail tests). PA - Positive affect; NA - Negative affect; EC Environmental concern; PCE - Perceived consumer effectiveness; PEB - Pro-environmental behaviour.

EC was predicted to be positively related to $\mathrm{PCE}(\mathrm{H} 3 \mathrm{a})$. This hypothesis is supported, given the positive coefficient that is statistically significant $(b=.59 ; \mathrm{p}<.01)$. EC was also predicted to relate positively to $\mathrm{PEB}$, but the results are not consistent with this prediction $(b=.06 ; p>.05)$, and thus $\mathrm{H} 3 \mathrm{~b}$ is rejected. Finally, PCE is related in a positive and statistically significant way with PEB $(b=.26 ; p<.01)$, and this accords with $\mathrm{H} 4$. 
As a further check on CMV, we also introduced a marker variable in the structural model, namely the degree of satisfaction with public health services, with paths to the dependent variables in the model. All of the paths that were previously statistically significant remained significant with the introduction of the marker variable. This also indicates that CVM is not a relevant concern.

To determine whether the effects of PA and NA on PEB were fully or partially mediated, we followed the recommendations in the literature (Zhao, Lynch, \& Chen, 2010), estimating indirect effects and assessing their significance with bootstrapping. PA is directly related to PEB, and the indirect effect is also statistically significant $(\mathrm{p}<.01)$. This implies that the effect of the former on PEB is partially mediated by PCE and EC. The results also indicate that the indirect effect of PA on PCE is positive and statistically significant $(\mathrm{p}<.01)$. Given that the direct effect is also significant, we obtained partial mediation. No statistically significant indirect effects emerged for NA, indicating that the effects of the latter are not mediated. Finally, EC is not directly related to PEB. However, its indirect effect through PCE is statistically significant $(\mathrm{p}<.01)$, indicating that the effect of EC on behaviour is fully mediated by PCE. Hence, concern influences behaviour to the extent to which it influences PCE.

\section{Discussion}

We now discuss the findings, first considering the results for the entire sample and, subsequently, for the multi-group analysis. Our results concerning PA are totally in line with our predictions, as it is positively related to EC, PCE and PEB. These positive relationships suggest that individuals scoring high on PA do not avoid negative information concerning the environment, namely about its increasing degradation, as a strategy to protect their feelings. Instead, a high PA appears to lead individuals to pay attention to such adverse information and to act upon it, namely by building their psychological resources (PCE), and by adopting behaviours that protect the environment (PEB). These consequences of PA are likely to result 
from the long term self-regulatory goals that PA promotes, including protection from threats as well as self-learning (Aspinwall, 1998). The results are also in line with the findings that PA builds an individual's resources, such as self-efficacy, and that it promotes individuals' engagement with the surrounding environment (Fredrickson, 1998; Lyubomirsky et al., 2005). Hence, the results we obtained provide evidence, from an environmental setting, that PA does not preclude the consideration of negative information in information processing and in decision making, and that in fact it may lead to enhanced attention and more thorough processing of such information (Aspinwall, 1998). Moreover, PA also exhibits an indirect significant relationship with PCE and PEB, implying that its effects are partially mediated. The existing knowledge suggests that the influence of PA and NA on constructs with a high behavioural content is, at least, partially mediated by other constructs (Curry \& Youngblade, 2006; Thoresen et al., 2003), and our results provide some support for this.

Bissing-Olson et al. (2013) posited that the influence of affect on PEB at work is moderated by EC. However, we predicted that affect is an antecedent of EC. The results we obtained support our view, which has been echoed in the literature. In fact, Forgas and George (2001, p. 4) observed that affect appears to guide the way people speak, the judgements they make about their colleagues, the way they relate to others, and their values and attitudes.

As to NA, we found that it only directly affects PEB. No significant relationships were established between NA, EC and PCE. We hypothesised that NA would be negatively related to EC and PCE based on evidence that individuals high in NA tend to emphasise negative things, namely about themselves, those around them, and the world in general (Watson \& Clark, 1984). It is possible that the non-significant effects result from countervailing forces associated with the narrowing of attention provoked by NA, which restricts the range of thoughts and actions that come to people's minds, and leads them to "miss the forest for the trees" (Fredrickson, 2001). Fredrickson (2001, p. 6) further notes that on occasions when survival is 
threatened, NA prompts action that brings immediate and direct adaptive benefits. There is also evidence that individuals with depressed moods are more concentrated on the possible costs than the possible benefits of specific risks (Pietromonaco \& Rook, 1987; Yuen \& Lee, 2003). This suggests that individuals high in NA will end-up having a more limited understanding of the natural environment, and that when the natural environment is evoked, fewer thoughts about it will come to these individuals' minds, which might erode the relationship between NA and EC. Concurrently, their reduced attentional focus may drive individuals to pay lower attention to the environment, making them indifferent concerning the development of their personal resources, i.e., PCE. Finally, the adoption of PEB is costly, which may lead individuals with higher NA to avoid them and engage instead in behaviours that yield immediate, rather than long-term benefits. This may explain why only the negative relationship between NA and PEB is supported.

Hence, PA appears to have a more important role in explaining PEB than NA, which is consistent with previous research pointing to the greater predictive power of PA over NA in other contexts (Djamasbi, Fruhling, \& Loiacono, 2009; Kafetsios \& Zampetakis, 2008). PA is likely to trigger more unusual and diverse associations, one reason being that it leads individuals to greater elaboration about an object and to reason in a more flexible way about it, perceiving both differences and similarities (Isen, 2008). This may result in a greater explanatory capacity for PA.

EC is strongly associated with PCE, which is a novel result. This finding is consistent with the proposition of other studies that individuals' beliefs and attitudes have behavioural effects (e.g., Gist \& Mitchell, 1992). We reasoned that the feelings of obligation emerging from EC drive individuals to explore how they could contribute to a better environment, and this appears to be supported. We also found that EC is not related to PEB. This, however, is not an original finding (Kilbourne \& Pickett, 2008). In fact, EC appears weakly related to pro-environmental 
consumer behaviour in many studies (Bamberg, 2003; Fransson \& Gärling, 1999; Kilbourne \& Pickett, 2008). A number of reasons have been advanced to explain such findings, including social norms, knowledge of environmental issues, and individuals' values, which may moderate such a relationship (Fransson \& Gärling, 1999). For example, the role of social norms can be quite salient. There is substantial evidence that "social norms can both spur and guide human behaviour" (Cialdini et al., 2006, p. 4), namely in a pro-environmental manner (e.g., Bamberg \& Schmidt, 2001; Schultz, Nolan, Cialdini, Goldstein, \& Griskevicius, 2007). Social norms can act as a moderator in the EC-PEB relationship. For example, an individual may decide to behave pro-environmentally even if he/she is not genuinely concerned about the environment, as long as he/she believes that people who are important to him/her perform the pro-environment behaviour or think he/she should perform such behaviour. The strength of the relationship between EC and PEB also hinges on the behavioural costs of undertaking PEB, i.e., lower costs facilitate the conversion of EC into PEB (Diekmann \& Preisendörfer, 2003). Notwithstanding the non-significance of the direct link between EC and PEB, EC has a significant indirect relationship with PEB through PCE. Hence, EC leads to PEB, to the extent to which it drives individuals' PCE.

Finally, PCE demonstrated a strong relationship with PEB. This is in line with previous studies that investigated the relationship between PCE and PEB or attitudes towards them (Kim \& Choi, 2005; Ohler \& Billger, 2014), as well as with the general self-efficacy literature that points to its strong motivational force and behavioural outcomes (Gist \& Mitchell, 1992; Wood \& Bandura, 1989).

The multi-group analysis indicates several differences between the sexes. Sex differences have been observed in studies investigating pro-environmental issues (Hunter, Hatch, \& Johnson, 2004; Kovács et al., 2014; Meinhold \& Malkus, 2005). Considering affect, we note that the moderating role of sex on the effects of PA and NA has been established in other studies 
(Kafetsios \& Zampetakis, 2008). A first observation in respect to sex differences in regard to affect is that we observed three significant paths for females, whereas for males only two were found. A possible explanation for this is that females experience emotions more strongly than males (Fujita, Diener, \& Sandvik, 1991), and this may ignite a larger number of consequences.

We observed that NA only relates directly to PEB in females. Past studies indicate that females are more prone to depression (Fujita et al., 1991). Hence it is possible that NA results in greater behavioural responses, namely environmental ones, in females. A further explanation is that females still have greater involvement with domestic tasks in Portugal, and this renders more cumbersome the tasks associated with PEB, namely recycling and energy saving actions. We also found that PA only relates to EC in females. It is possible that this results from the socialisation process of women, whose traditional caretaker role might lead them to develop more altruistic values (Dietz, Kalof, \& Stern, 2002).

The results indicate that PA and EC are only related to PEB in males. A possible explanation for this might be that males can be more assertive than females, as evidenced by meta-analyses (Feingold, 1994; Maccoby \& Jacklin, 1974). Assertiveness can be defined as "a person's tendency to actively defend, pursue, and speak out for his or her own interests" (Ames \& Flynn, 2007, p. 307). That is to say, it is an enduring disposition to express oneself (Ray, 1981), including offering and requesting assistance in case of need, stating and keeping opinions, and initiating action that solves problems and addresses needs (Lorr \& More, 1980; Smith-Jentsch \& Salas, 1996). Hence, it is possible that the greater assertiveness of males, with their higher behavioural predisposition, is at the root of the differentiated results for males and females regarding the PA-PEB and EC-PEB links.

\section{Implications}

Our study has relevant implications for firms with a more environmental friendly stance, advertising agencies, environmental associations, and public policy makers. In line with 
research on personality traits and PEB (e.g., Markowitz et al., 2012), this study indicates that the promotion of PEB should pay attention to stable individual differences such as trait affective experiences. PA is positively related to PEB, whereas NA is negatively related to it. Notwithstanding this, the literature indicates that in some circumstances, individuals high in NA adopt helping behaviours, namely when they think they have harmed others, when they think they can ameliorate their own mood, or when the costs of helping are low compared to the respective benefits (Lyubomirsky et al., 2005). These insights could be used to lead individuals high in NA to act in a more environmentally-friendly way. Accordingly, a reduction in the hassles associated with PEB, such as recycling, should increase the likelihood of such individuals adopting environmentally-friendly behaviours. This may involve increasing the number of recycling points, implementing a door-to-door system for the collection of recycling material, and utilising product packaging that minimises the hassle of recycling.

Moreover, Markowitz et al. (2012) argue that advertising can be used to take advantage or deal with the relationship between individuals' personality traits and the adoption of PEB. Accordingly, advertising could show how individuals' feelings might improve with the adoption of PEB, as well as pinpointing that acting otherwise may harm others. This should drive not only individuals high in NA, but also those high in PA, to act in a more environmentally-friendly way. Likewise, labels could be used to convey how PEB might uplift individuals' subjective experiences.

Our results indicate that EC is related to PEB for males. This reinforces the need for environmental policy initiatives that foster concern and combat factors that may act to distort the effects of EC on environmental behaviour, such as materialism. As to PCE, the results suggest that marketing communication should try to convince people that their individual efforts have powerful collective impacts. Activating PCE should involve regular communication about the results of individuals' actions to convey the message that they are 
contributing to solving the problem (e.g., Ellen et al., 1991; Roberts, 1996), such as posting notices in shopping centre toilets about the amount of water saved in the previous year. Moreover, campaigns should also be developed in order to improve individuals' knowledge about how they can contribute to a better environment, as such knowledge leads to environmentally-friendly behaviours.

\section{Limitations of the study and directions for future research}

The results obtained in this study must be viewed in the light of their limitations. We relied on a single informant to collect information on the dependent and independent variables. This may have contributed to $\mathrm{CMV}$, which inflates construct interrelationships. To minimise this possibility, we relied on a number of procedural remedies (Podsakoff, MacKenzie, Lee, \& Podsakoff, 2003): the respondents were not informed about the conceptual framework of interest, which should have reduced the response bias; we relied primarily on previously used and validated scales, which should have minimised the measurement error associated with scale construction; item ambiguity and biased responding were also minimised by labelling each scale point and pre-testing the questionnaire; the respondents were assured of the confidentiality and anonymity of their responses, and that there were no right or wrong answers, which should have reduced their evaluation apprehension and social desirability bias, minimising the response bias (Podsakoff et al., 2003); the respondents were motivated to participate in the study, with the cover letter indicating the importance of respondents' response to the success of the study; and the dependent and independent variables were placed in different blocks of the questionnaire, so as to create a proximal distance between the constructs. As previously described, we also conducted a number of statistical tests to ascertain the magnitude of CMV. The cumulative evidence from these tests suggests that CMV does not threaten the results and interpretations. 
Another limitation of this study is its cross-sectional nature, which precludes causality inferences. Accordingly, it would be interesting to conduct studies in which the independent and dependent variables are collected at different points in time, so as to shed light on the relationships between these variables over time. Moreover, the sample has a sex imbalance, which, nonetheless, we have addressed by controlling for this variable. The sample was also obtained from a particular region of a country, and therefore caution should be exercised in terms of the generalisability of the findings to other contexts. Hence, external validation of the findings would require a replication of the study in other settings.

An additional limitation is the omission of normative processes, which have been recognised as important drivers of PEB (e.g., Bamberg \& Schmidt, 2001; Schultz et al., 2007). Hence, a research avenue worth pursuing consists of expanding the model to consider the role of such normative processes. We have already discussed its potential moderator role in the ECPEB link, but it seems equally likely that subjective norms also moderate the relationship between affect and the outcome variables. In addition, the paths we have predicted and tested may also be moderated by other variables, including knowledge of environmental issues, the costs associated with the adoption of environmental behaviours, and individuals' values. Moreover, the moderating effect of age could also be explored, which would provide insights into how individuals' attitudes and behaviours evolve across time. This appears quite relevant, as individuals of different ages are likely to have been exposed to different degrees of environmental degradation and media information throughout their lives.

This research investigated the relationship between affect and general PEB. However, it is possible that the response of individuals to affect may change according to the type of PEB, including water saving, energy conservation and recycling, and this is worth investigating. It would also be relevant to assess whether the results differ significantly with an analysis based on actual (rather than reported) behaviours. Furthermore, results can be sensitive to the 
measurement of PEB. For instance, measures developed with an intent-oriented focus, i.e. based on behaviours performed with the intention to benefit the environment, despite their small environmental effects, or with an impact-oriented focus, i.e. relying on behaviours that significantly impact the environment, have different antecedents (e.g., Gatersleben, Steg, \& Vlek, 2002; Poortinga, Steg, \& Vlek, 2004). Moreover, motivational variables such as attitudes and personal norms seem to be more effective in changing low-cost behaviours than high-cost behaviours (Gatersleben et al., 2002). Finally, this study considered the mediating mechanisms of EC and PCE. However, it is possible that other variables mediate the relationship between affect and environmental behaviours. Hence, future research might consider alternative mediating mechanisms.

\section{Conclusion}

In summary, this study successfully associates affect, as a stable individual difference, with reported PEB. Previous research on PEB and affect has essentially looked at how the emotions anticipated from the adoption of certain environmentally-friendly behaviours drive their implementation (the exception being Bissing-Olson et al. (2013), who linked state (daily) affect with PEB). In this context, our study makes a strong departure from previous research. Moreover, the new results obtained in this study suggest that considering trait affect in environmental behaviour studies could yield significant contributions to different areas of research, namely by expanding our understanding of what motivates PEB and by improving our comprehension of the role of trait affect in different contexts. Finally, this study warrants future research exploring the relationship between trait affect and alternative cognitions and psychological resources that might be associated with PEB. 


\section{References}

Akehurst, G., Afonso, C., \& Gonçalves, H. M. (2012). Re-examining green purchase behaviour and the green consumer profile: new evidences. Management Decision, 50(5), 972-988. http://doi.org/10.1108/00251741211227726

Ames, D. R., \& Flynn, F. J. (2007). What breaks a leader: the curvilinear relation between assertiveness and leadership. Journal of Personality and Social Psychology, 92(2), 307-324. http://doi.org/10.1037/0022-3514.92.2.307

Aspinwall, L. G. (1998). Rethinking the Role of Positive Affect in Self-Regulation. Motivation and Emotion, 22(1), 1-32. http://doi.org/10.1023/A:1023080224401

Axelrod, L. J., \& Lehman, D. R. (1993). Responding to environmental concerns: What factors guide individual action? Journal of Environmental Psychology, 13(2), 149-159. http://doi.org/10.1016/S0272-4944(05)80147-1

Bamberg, S. (2003). How does environmental concern influence specific environmentally related behaviors? A new answer to an old question. Journal of Environmental Psychology, 23(1), 2132. http://doi.org/10.1016/S0272-4944(02)00078-6

Bamberg, S., \& Möser, G. (2007). Twenty years after Hines, Hungerford, and Tomera: A new metaanalysis of psycho-social determinants of pro-environmental behaviour. Journal of Environmental Psychology, 27(1), 14-25. http://doi.org/10.1016/j.jenvp.2006.12.002

Bamberg, S., \& Schmidt, P. (2001). Theory-Driven Subgroup-Specific Evaluation of an Intervention to Reduce Private Car Use1. Journal of Applied Social Psychology, 31(6), 1300-1329. http://doi.org/10.1111/j.1559-1816.2001.tb02675.x

Bandalos, D. L. (2002). The effects of item parceling on goodness-of-fit and parameter estimate bias in structural equation modeling. Structural Equation Modeling: A Multidisciplinary Journal, 9(1), 78-102. http://doi.org/10.1207/S15328007SEM0901_5

Bissing-Olson, M. J., Iyer, A., Fielding, K. S., \& Zacher, H. (2013). Relationships between daily affect and pro-environmental behavior at work: the moderating role of pro-environmental attitude. Journal of Organizational Behavior, J. Organiz. Behav., 34(1), 156-175. http://doi.org/10.1002/job

Bolger, N., \& Schilling, E. A. (1991). Personality and the problems of everyday life: the role of neuroticism in exposure and reactivity to daily stressors. Journal of Personality, 59(3), 355-386. http://doi.org/10.1111/j.1467-6494.1991.tb00253.x

Brick, C., \& Lewis, G. J. (2014). Unearthing the "Green" Personality. Environment and Behavior, 48(5), 635-658. http://doi.org/10.1177/0013916514554695 
Brief, A. P., Butcher, A. H., \& Roberson, L. (1995). Cookies, disposition, and job attitudes: The effects of positive mood-inducing events and negative affectivity on job satisfaction in a field experiment. Organizational Behavior and Human Decision Processes, 62(1), 55-62. http://doi.org/10.1006/obhd.1995.1030

Carrus, G., Passafaro, P., \& Bonnes, M. (2008). Emotions, habits and rational choices in ecological behaviours: The case of recycling and use of public transportation. Journal of Environmental Psychology, 28(1), 51-62. http://doi.org/10.1016/j.jenvp.2007.09.003

Chan, R. Y. K. (2001). Determinants of Chinese consumers' green purchase behavior. Psychology and Marketing, 18(4), 389-413. http://doi.org/10.1002/mar.1013

Chaudhuri, A., \& Ligas, M. (2009). Consequences of Value in Retail Markets. Journal of Retailing, 85(3), 406-419. http://doi.org/10.1016/j.jretai.2009.05.006

Cialdini, R. B., Demaine, L. J., Sagarin, B. J., Barrett, D. W., Rhoads, K., \& Winter, P. L. (2006). Managing social norms for persuasive impact. Social Influence, 1(1), 3-15. http://doi.org/10.1080/15534510500181459

Coffman, D. L., \& MacCallum, R. C. (2005). Using Parcels to Convert Path Analysis Models Into Latent Variable Models. Multivariate Behavioral Research, 40(2), 235-259. http://doi.org/10.1207/s15327906mbr4002_4

Cordano, M., Welcomer, S. a, \& Scherer, R. F. (2003). An Analysis of the Predictive Validity of the New Ecological Paradigm Scale. Journal of Environmental Education, 34(3), 22-28. http://doi.org/10.1080/00958960309603490

Cunningham, M. R. (1988). Does Happiness Mean Friendliness?: Induced Mood and Heterosexual Self-Disclosure. Personality and Social Psychology Bulletin, 14(2), 283-297. http://doi.org/10.1177/0146167288142007

Curry, L. A., \& Youngblade, L. M. (2006). Negative affect, risk perception, and adolescent risk behavior. Journal of Applied Developmental Psychology, 27(5), 468-485. http://doi.org/10.1016/j.appdev.2006.06.001

Diekmann, A., \& Preisendörfer, P. (2003). Green and Greenback. Rationality and Society, 15(4), 441472. http://doi.org/10.1177/1043463103154002

Dietz, T., Kalof, L., \& Stern, P. C. (2002). Gender, Values, and Environmentalism. Social Science Quarterly, 83(1), 353-364. http://doi.org/10.1111/1540-6237.00088

Djamasbi, S., Fruhling, A. L., \& Loiacono, E. T. (2009). The Influence of Affect, Attitude and Usefulness in the Acceptance of Telemedicine Systems. JITTA: Journal of Information Technology Theory and Application, 10(1), 41-58. 
Dua, J. K. (1993). The role of negative affect and positive affect in stress, depression, self-esteem, assertiveness, Type A behaviors, psychological health, and physical health. Genetic, Social, and General Psychology Monographs, 119(4), 515-552.

Dunlap, R. E., Liere, K. D. Van, Mertig, A. G., \& Jones, R. E. (2000). Measuring Endorsement of the New Ecological Paradigm : A Revised NEP Scale. Journal of Social Issues, 56(3), 425-442. http://doi.org/10.1111/0022-4537.00176

Ellen, P. S., Wiener, J. L., \& Cobb-Walgren, C. (1991). The Role of Perceived Consumer Effectiveness in Motivating Environmentally Conscious Behaviors. Journal of Public Policy \& Marketing, 10(2), 102-117.

Fan, X., \& Wang, L. (1998). Effects of Potential Confounding Factors on Fit Indices and Parameter Estimates for True and Misspecified SEM Models. Educational and Psychological Measurement, 58(5), 701-735. http://doi.org/10.1177/0013164498058005001

Feingold, A. (1994). Gender differences in personality: a meta-analysis. Psychological Bulletin, 116(3), 429-456. http://doi.org/10.1037/0033-2909.116.3.429

Forgas, J. P., \& George, J. M. (2001). Affective Influences on Judgments and Behavior in Organizations: An Information Processing Perspective. Organizational Behavior and Human Decision Processes, 86(1), 3-34. http://doi.org/10.1006/obhd.2001.2971

Fornell, C., \& Larcker, D. F. (1981). Evaluating Structural Equation Models with Unobservable Variables and Measurement Error. Journal of Marketing Research, 18(1), 39-50. http://doi.org/10.2307/3151312

Fransson, N., \& Gärling, T. (1999). Environmental concern: conceptual definitions, measurement methods, and research findings. Journal of Environmental Psychology, 19(4), 369-382. http://doi.org/10.1006/jevp.1999.0141

Fredrickson, B. L. (1998). What Good Are Positive Emotions? Review of General Psychology: Journal of Division 1, of the American Psychological Association, 2(3), 300-319. http://doi.org/10.1037/1089-2680.2.3.300

Fredrickson, B. L. (2001). The Role of Positive Emotions in Positive Psychology: The Broaden-andBuild Theory of Positive Emotions. The American Psychologist, 56(3), 218-226. http://doi.org/10.1037/0003-066X.56.3.218

Fujita, F., Diener, E., \& Sandvik, E. (1991). Gender differences in negative affect and well-being: the case for emotional intensity. Journal of Personality and Social Psychology, 61(3), 427-434. http://doi.org/10.1037//0022-3514.61.3.427

Gardner, G. T., \& Stern, P. C. (1996). Environmental Problems and Human Behavior. Boston, MA: 
Allyn and Bacon.

Gatersleben, B., Steg, L., \& Vlek, C. (2002). Measurement and Determinants of Environmentally Significant Consumer Behavior. Environment and Behavior, 34(3), 335-362. http://doi.org/10.1177/0013916502034003004

Giluk, T. L. (2009). Mindfulness, Big Five personality, and affect: A meta-analysis. Personality and Individual Differences, 47(8), 805-811. http://doi.org/http://dx.doi.org/10.1016/j.paid.2009.06.026

Gist, M. E., \& Mitchell, T. R. (1992). Self-Efficacy: A Theoretical Analysis of Its Determinants and Malleability. The Academy of Management Review, 17(2), 183-211. http://doi.org/10.2307/258770

Goldberg, L. R. (1990). An alternative "description of personality": The Big-Five factor structure. Journal of Personality and Social Psychology. US: American Psychological Association. http://doi.org/10.1037/0022-3514.59.6.1216

Han, H. (2014). The norm activation model and theory-broadening: Individuals' decision-making on environmentally-responsible convention attendance. Journal of Environmental Psychology, 40, 462-471. http://doi.org/10.1016/j.jenvp.2014.10.006

Han, H., Hwang, J., \& Lee, S. (2017). Cognitive, affective, normative, and moral triggers of sustainable intentions among convention-goers. Journal of Environmental Psychology, 51, 1-13. http://doi.org/10.1016/j.jenvp.2017.03.003

Harth, N. S., Leach, C. W., \& Kessler, T. (2013). Guilt, anger, and pride about in-group environmental behaviour: Different emotions predict distinct intentions. Journal of Environmental Psychology, 34, 18-26. http://doi.org/10.1016/j.jenvp.2012.12.005

Hartmann, P., \& Apaolaza-Ibáñez, V. (2012). Consumer attitude and purchase intention toward green energy brands: The roles of psychological benefits and environmental concern. Journal of Business Research, 65(9), 1254-1263. http://doi.org/10.1016/j.jbusres.2011.11.001

Hines, J. M., Hungerford, H. R., \& Tomera, A. N. (1987). Analysis and Synthesis of Research on Responsible Environmental Behavior: A Meta-Analysis. The Journal of Environmental Education, 18(2), 1-8. http://doi.org/10.1080/00958964.1987.9943482

Hirsh, J. B. (2010). Personality and environmental concern. Journal of Environmental Psychology, 30(2), 245-248. http://doi.org/10.1016/j.jenvp.2010.01.004

Hom, H. L., \& Arbuckle, B. (1988). Mood induction effects upon goal setting and performance in young children. Motivation and Emotion, 12(2), 113-122. http://doi.org/10.1007/BF00992168

Hori, S., Kondo, K., Nogata, D., \& Ben, H. (2013). The determinants of household energy-saving 
behavior: Survey and comparison in five major Asian cities. Energy Policy, 52, 354-362. http://doi.org/10.1016/j.enpol.2012.09.043

Hunter, L. M., Hatch, A., \& Johnson, A. (2004). Cross-National Gender Variation in Environmental Behaviors. Social Science Quarterly, 85(3), 677-694. http://doi.org/10.1111/j.00384941.2004.00239.x

Isen, A. M. (2008). Positive affect and decision making. In M. Lewis, J. Haviland-Jones, \& L. F. Barrett (Eds.), Handbook of Emotions (3rd ed., pp. 548-573). New York: Guilford.

Isen, A. M., Shalker, T. E., Clark, M., \& Karp, L. (1978). Affect, accessibility of material in memory, and behavior: a cognitive loop? Journal of Personality and Social Psychology, 36(1), 1-12. http://doi.org/org/10.1037/0022-3514.36.1.1

Judge, T. A., Erez, A., \& Thoresen, C. J. (2000). Why negative affectivity (and self-deception) should be included in job stress research: bathing the baby with the bath water. Journal of Organizational Behavior, 21(1), 101-111. http://doi.org/10.1002/(SICI)10991379(200002)21:13.0.CO;2-Q

Jundt, D., \& Hinsz, V. B. (2001). Are happier workers more productive workers? The impact of mood on self-set goals, self-efficacy, and task performance. In Annual meeting of the Midwestern Psychological Association.

Kafetsios, K., \& Zampetakis, L. A. (2008). Emotional intelligence and job satisfaction: Testing the mediatory role of positive and negative affect at work. Personality and Individual Differences, 44(3), 712-722. http://doi.org/10.1016/j.paid.2007.10.004

Kals, E., Schumacher, D., \& Montada, L. (1999). Emotional affinity toward nature as a motivational basis to protect nature. Environment and Behavior, 31(2), 178-202. http://doi.org/10.1177/00139169921972056

Kavanagh, D. J., \& Bower, G. H. (1985). Mood and self-efficacy: Impact of joy and sadness on perceived capabilities. Cognitive Therapy and Research, 9(5), 507-525. http://doi.org/10.1007/BF01173005

Kilbourne, W., \& Pickett, G. (2008). How materialism affects environmental beliefs, concern, and environmentally responsible behavior. Journal of Business Research, 61(9), 885-893. http://doi.org/10.1016/j.jbusres.2007.09.016

Kim, Y., \& Choi, M. S. (2005). Antecedents of Green Purchase Behavior: An Examination of Collectivism, Environmental Concern, and PCE. Advances in Consumer Research, 32(1), 592599. http://doi.org/10.1177/004057368303900411

Kinnear, T. C., Taylor, J. R., \& Ahmed, S. A. (1974). Ecologically Concerned Consumers: Who Are 
They? Journal of Marketing, 38(2), 20-24. http://doi.org/10.2307/1250192

Kline, R. B. (2011). Principles and practice of structural equation modelling (3rd ed.). London: The Guilford Press.

Koenig-Lewis, N., Palmer, A., Dermody, J., \& Urbye, A. (2014). Consumers' evaluations of ecological packaging - Rational and emotional approaches. Journal of Environmental Psychology, 37, 94-105. http://doi.org/10.1016/j.jenvp.2013.11.009

Kollmuss, A., \& Agyeman, J. (2002). Mind the Gap: Why do people act environmentally and what are the barriers to pro-environmental behavior? Environmental Education Research, 8(3), 239-260. http://doi.org/10.1080/13504620220145401

Kovács, J., Pántya, J., Medvés, D., Hidegkuti, I., Heim, O., \& Bursavich, J. B. (2014). Justifying environmentally significant behavior choices: An American-Hungarian cross-cultural comparison. Journal of Environmental Psychology, 37, 31-39. http://doi.org/10.1016/j.jenvp.2013.11.001

Kuiper, N. A., McKee, M., Kazarian, S. S., \& Olinger, J. L. (2000). Social perceptions in psychiatric inpatients: relation to positive and negative affect levels. Personality and Individual Differences, 29(3), 479-493. http://doi.org/10.1016/S0191-8869(99)00209-3

Larsen, R. J., \& Ketelaar, T. (1991). Personality and susceptibility to positive and negative emotional states. Journal of Personality and Social Psychology, 61(1), 132-140. http://doi.org/10.1037//0022-3514.61.1.132

Lee, Y.-K., Kim, S., Kim, M., \& Choi, J. (2014). Antecedents and interrelationships of three types of pro-environmental behavior. Journal of Business Research, 67(10), 2097-2105. http://doi.org/10.1016/j.jbusres.2014.04.018

Lei, M., \& Lomax, R. G. (2005). The Effect of Varying Degrees of Nonnormality in Structural Equation Modeling. Structural Equation Modeling: A Multidisciplinary Journal, 12(1), 1-27. http://doi.org/10.1207/s15328007sem1201_1

Lin, P. C., \& Huang, Y. H. (2012). The influence factors on choice behavior regarding green products based on the theory of consumption values. Journal of Cleaner Production, 22(1), 11-18. http://doi.org/10.1016/j.jclepro.2011.10.002

Little, T. D., Cunningham, W. A., Shahar, G., \& Widaman, K. F. (2002). To Parcel or Not to Parcel: Exploring the Question, Weighing the Merits. Structural Equation Modeling: A Multidisciplinary Journal (Vol. 9). Routledge. http://doi.org/10.1207/S15328007SEM0902_1

Little, T. D., Rhemtulla, M., Gibson, K., \& Schoemann, A. M. (2013). Why the Items Versus Parcels Controversy Needn’t Be One. Psychological Methods, 18(3), 285-300. 
http://doi.org/10.1037/a0033266

López-Mosquera, N., Lera-López, F., \& Sánchez, M. (2015). Key factors to explain recycling, car use and environmentally responsible purchase behaviors: A comparative perspective. Resources, Conservation and Recycling, 99, 29-39. http://doi.org/10.1016/j.resconrec.2015.03.007

Lorr, M., \& More, W. W. (1980). Four Dimensions Of Assertiveness. Multivariate Behavioral Research, 15(2), 127-138. http://doi.org/10.1207/s15327906mbr1502_1

Lu, H., \& Schuldt, J. P. (2016). Compassion for climate change victims and support for mitigation policy. Journal of Environmental Psychology, 45, 192-200. http://doi.org/10.1016/j.jenvp.2016.01.007

Lyubomirsky, S., King, L., \& Diener, E. (2005). The benefits of frequent positive affect: Does happiness lead to success? Psychological Bulletin, 131(6), 803-855. http://doi.org/10.1037/00332909.131.6.803

Maccoby, E. E., \& Jacklin, C. N. (1974). The psychology of sex differences. CA: Stanford University Press.

Mackinnon, A., Jorm, A. F., Christensen, H., Korten, A. E., Jacomb, P. A., \& Rodgers, B. (1999). A short form of the Positive and Negative Affect Schedule: evaluation of factorial validity and invariance across demographic variables in a community sample. Personality and Individual Differences, 27(3), 405-416. http://doi.org/10.1016/S0191-8869(98)00251-7

Markowitz, E. M., Goldberg, L. R., Ashton, M. C., \& Lee, K. (2012). Profiling the "pro-environmental individual”: A personality perspective. Journal of Personality, 80(1), 81-111. http://doi.org/10.1111/j.1467-6494.2011.00721.x

Mayer, F. S., \& Frantz, C. M. (2004). The connectedness to nature scale: A measure of individuals' feeling in community with nature. Journal of Environmental Psychology, 24(4), 503-515. http://doi.org/10.1016/j.jenvp.2004.10.001

Meinhold, J. L., \& Malkus, A. J. (2005). Adolescent Environmental Behaviors: Can Knowledge, Attitudes, and Self-Efficacy Make a Difference? Environment and Behavior, 37(4), 511-532. http://doi.org/10.1177/0013916504269665

Mezzich, A. C., Tarter, R. E., Giancola, P. R., Lu, S., Kirisci, L., \& Parks, S. (1997). Substance use and risky sexual behavior in female adolescents. Drug and Alcohol Dependence, 44(2-3), 157166. http://doi.org/10.1016/S0376-8716(96)01333-6

Milfont, T. L., \& Duckitt, J. (2004). The structure of environmental attitudes: A first- and secondorder confirmatory factor analysis. Journal of Environmental Psychology, 24(3), 289-303. http://doi.org/10.1016/j.jenvp.2004.09.001 
Milfont, T. L., \& Duckitt, J. (2010). The environmental attitudes inventory: A valid and reliable measure to assess the structure of environmental attitudes. Journal of Environmental Psychology, 30(1), 80-94. http://doi.org/10.1016/j.jenvp.2009.09.001

Milfont, T. L., \& Sibley, C. G. (2012). The big five personality traits and environmental engagement: Associations at the individual and societal level. Journal of Environmental Psychology, 32(2), 187-195. http://doi.org/10.1016/j.jenvp.2011.12.006

Necowitz, L. B., \& Roznowski, M. (1994). Negative Affectivity and Job Satisfaction: Cognitive Processes Underlying the Relationship and Effects on Employee Behaviors. Journal of Vocational Behavior, 45(3), 270-294. http://doi.org/10.1006/jvbe.1994.1036

Obermiller, C. (1995). The baby is sick/the baby is well: a test of environmental communication appeals. Journal of Advertising, 24(2), 55-70. http://doi.org/10.1080/00913367.1995.10673476

Ohler, A. M., \& Billger, S. M. (2014). Does environmental concern change the tragedy of the commons? Factors affecting energy saving behaviors and electricity usage. Ecological Economics, 107, 1-12. http://doi.org/10.1016/j.ecolecon.2014.07.031

Park, J., \& Ha, S. (2012). Understanding pro-environmental behavior: A comparison of sustainable consumers and apathetic consumers. International Journal of Retail \& Distribution Management, 40(5), 388-403. http://doi.org/10.1108/09590551211222367

Passafaro, P., Rimano, A., Piccini, M. P., Metastasio, R., Gambardella, V., Gullace, G., \& Lettieri, C. (2014). The bicycle and the city: Desires and emotions versus attitudes, habits and norms. Journal of Environmental Psychology, 38, 76-83. http://doi.org/10.1016/j.jenvp.2013.12.011

Perugini, M., \& Bagozzi, R. P. (2001). The role of desires and anticipated emotions in goal-directed behaviours: Broadening and deepening the theory of planned behaviour. British Journal of Social Psychology, 40(1), 79-98. http://doi.org/10.1348/014466601164704

Pietromonaco, P. R., \& Rook, K. S. (1987). Decision style in depression: The contribution of perceived risks versus benefits. Journal of Personality and Social Psychology, 52(2), 399-408. http://doi.org/10.1037/0022-3514.52.2.399

Podsakoff, P. M., MacKenzie, S. B., Lee, J.-Y., \& Podsakoff, N. P. (2003). Common method biases in behavioral research: a critical review of the literature and recommended remedies. The Journal of Applied Psychology, 88(5), 879-903. http://doi.org/10.1037/0021-9010.88.5.879

Pooley, J. A., \& O'Connor, M. (2000). Environmental Education and Attitudes: Emotions and Beliefs Are What Is Needed. Environment \& Behaviour, 32(5), 711-723. http://doi.org/10.1177/0013916500325007

Poortinga, W., Steg, L., \& Vlek, C. (2004). Values, Environmental Concern, and Environmental 
Behavior: A Study into Household Energy Use. Environment and Behavior, 36(1), 70-93. http://doi.org/10.1177/0013916503251466

Ray, J. J. (1981). Authoritarianism, dominance and assertiveness. Journal of Personality Assessment, 45(4), 390-397. http://doi.org/10.1207/s15327752jpa4504_8

Rhead, R., Elliot, M., \& Upham, P. (2015). Assessing the structure of UK environmental concern and its association with pro-environmental behaviour. Journal of Environmental Psychology, 43, 175-183. http://doi.org/10.1016/j.jenvp.2015.06.002

Robbins, S. P., Judge, T. A., Millett, B., \& Jones, M. (2010). OB: The Essentials. Sydney, Australia: Pearson Education.

Roberts, J. A. (1996). Green consumers in the 1990s: Profile and implications for advertising. Journal of Business Research, 36(3), 217-231. http://doi.org/10.1016/0148-2963(95)00150-6

Russell, J. A., \& Carroll, J. M. (1999). On the bipolarity of positive and negative affect. Psychological Bulletin, 125(1), 3-30. http://doi.org/10.1037/0033-2909.125.1.3

Samnani, A.-K., Salamon, S. D., \& Singh, P. (2014). Negative Affect and Counterproductive Workplace Behavior: The Moderating Role of Moral Disengagement and Gender. Journal of Business Ethics, 119(2), 235-244. http://doi.org/10.1007/s10551-013-1635-0

Sardianou, E. (2008). Estimating space heating determinants: An analysis of Greek households. Energy and Buildings, 40(6), 1084-1093. http://doi.org/10.1016/j.enbuild.2007.10.003

Schaubroeck, J., Ganster, D. C., \& Kemmerer, B. (2016). Does Trait Affect Promote Job Attitude Stability? Journal of Organizational Behavior, 17(2), 191-196.

Schultz, P. W., Nolan, J. M., Cialdini, R. B., Goldstein, N. J., \& Griskevicius, V. (2007). The Constructive, Destructive, and Reconstructive Power of Social Norms. Psychological Science, 18(5), 429-434. http://doi.org/10.1111/j.1467-9280.2007.01917.x

Schwartz, S. H. (1977). Normative Influences on Altruism. Advances in Experimental Social Psychology, 10, 221-279. http://doi.org/10.1016/S0065-2601(08)60358-5

Smith-Jentsch, K. A., \& Salas, E. (1996). Training Team Performance-Related Assertiveness. Personnel Psychology, 49(4), 909-936. http://doi.org/10.1111/j.1744-6570.1996.tb02454.x

Steg, L., \& Vlek, C. (2009). Encouraging pro-environmental behaviour: An integrative review and research agenda. Journal of Environmental Psychology, 29(3), 309-317. http://doi.org/10.1016/j.jenvp.2008.10.004

Stern, P. C. (2000). Toward a Coherent Theory of Environmentally Significant Behavior. Journal of Social Issues, 56(3), 407-424. http://doi.org/10.1111/0022-4537.00175 
Terrier, L., Kim, S., \& Fernandez, S. (2016). Who are the good organizational citizens for the environment? An examination of the predictive validity of personality traits. Journal of Environmental Psychology, 48, 185-190. http://doi.org/10.1016/j.jenvp.2016.10.005

Thompson, S. C. (1981). Will it hurt less if i can control it? A complex answer to a simple question. Psychological Bulletin, 90(1), 89-101. http://doi.org/10.1037/0033-2909.90.1.89

Thoresen, C. J., Kaplan, S. A., Barsky, A. P., Warren, C. R., \& de Chermont, K. (2003). The affective underpinnings of job perceptions and attitudes: a meta-analytic review and integration. Psychological Bulletin, 129(6), 914-945. http://doi.org/10.1037/0033-2909.129.6.914

Trope, Y., \& Pomerantz, E. M. (1998). Resolving Conflicts Among Self-Evaluative Motives: Positive Experiences as a Resource for Overcoming Defensiveness. Motivation and Emotion, 22(1), 5372. http://doi.org/10.1023/A:1023044625309

Vaske, J. J., \& Kobrin, K. C. (2001). Place attachment and environmentally responsible behavior. The Journal of Environmental Education, 32(4), 16-21. http://doi.org/10.1080/00958960109598658

Vicente-Molina, M. A., Fernández-Sáinz, A., \& Izagirre-Olaizola, J. (2013). Environmental knowledge and other variables affecting pro-environmental behaviour: comparison of university students from emerging and advanced countries. Journal of Cleaner Production, 61, 130-138. http://doi.org/10.1016/j.jclepro.2013.05.015

Vining, J., \& Ebreo, A. (2002). Emerging theoretical and methodological perspectives on conservation behavior. In R. B. Bechtel \& A. Churchman (Eds.), Handbook of Environmental Psychology (pp. 551-558). New York: Wiley.

Wang, G., \& Netemyer, R. G. (2002). The effects of job autonomy, customer demandingness, and trait competitiveness on salesperson learning, self-efficacy, and performance. Journal of the Academy of Marketing Science, 30(3), 217-228. http://doi.org/10.1177/0092070302303003

Watson, D. (2000). Mood and temperament. New York: Guilford Press.

Watson, D., \& Clark, L. A. (1984). Negative affectivity: the disposition to experience aversive emotional states. Psychological Bulletin, 96(3), 465-490. http://doi.org/10.1037/00332909.96.3.465

Watson, D., Clark, L. A., \& Tellegen, A. (1988). Development and validation of brief measures of positive and negative affect: the PANAS scales. Journal of Personality and Social Psychology, 54(6), 1063-1070. http://doi.org/10.1037/0022-3514.54.6.1063

Watson, D., \& Hubbard, B. (1996). Adaptational Style and Dispositional Structure: Coping in the Context of the Five-Factor Model. Journal of Personality, 64(4), 737-774. http://doi.org/10.1111/j.1467-6494.1996.tb00943.x 
Watson, D., Wiese, D., Vaidya, J., \& Tellegen, A. (1999). The two general activation systems of affect: Structural findings, evolutionary considerations, and psychobiological evidence. Journal of Personality and Social Psychology, 76(5), 820-838. http://doi.org/10.1037/00223514.76.5.820

Webster, F. E. (1975). Determining the Characteristics of the Socially Conscious Consumer. Journal of Consumer Research, 2(3), 188-196. http://doi.org/10.1086/208631

Weiss, H. M., \& Cropanzano, R. (1996). Affective Events Theory: A theoretical discussion of the structure, causes and consequences of affective experiences at work. Research in Organizational Behavior: An Annual Series of Analytical Essays and Critical Reviews, 18, 1-74.

Wester, J., Timpano, K. R., Çek, D., Lieberman, D., Fieldstone, S. C., \& Broad, K. (2015). Psychological and social factors associated with wastewater reuse emotional discomfort. Journal of Environmental Psychology, 42, 16-23. http://doi.org/10.1016/j.jenvp.2015.01.003

Wong, J., Newton, J. D., \& Newton, F. J. (2016). Powerlessness following service failure and its implications for service recovery. Marketing Letters, 27(1), 63-75. http://doi.org/10.1007/s11002-014-9303-4

Wood, R., \& Bandura, A. (1989). Impact of conceptions of ability on self-regulatory mechanisms and complex decision making. Journal of Personality and Social Psychology, 56(3), 407-415. http://doi.org/10.1037/0022-3514.56.3.407

Wyer, R. S., Clore, G. L., \& Isbell, L. M. (1999). Affect and Information Processing. Advances in Experimental Social Psychology, 31, 1-77. http://doi.org/10.1016/S0065-2601(08)60271-3

Yuen, K. S. L., \& Lee, T. M. C. (2003). Could mood state affect risk-taking decisions? Journal of Affective Disorders, 75(1), 11-18. http://doi.org/10.1016/S0165-0327(02)00022-8

Zhao, H., Gao, Q., Wu, Y., Wang, Y., \& Zhu, X. (2014). What affects green consumer behavior in China? A case study from Qingdao. Journal of Cleaner Production, 63, 143-151. http://doi.org/10.1016/j.jclepro.2013.05.021

Zhao, X., Lynch, J. G., \& Chen, Q. (2010). Reconsidering Baron and Kenny: Myths and Truths about Mediation Analysis. Journal of Consumer Research, 37(2), 197-206. http://doi.org/10.1086/651257 